\title{
PENGARUH PRODUK DAN TEMPAT TERHADAP TINGKAT KEPUASAN \\ PESERTA PELATIHAN KEWIRAUSAHAAN DAN PENYUSUNAN ANGGARAN \\ BAGI PELAKU UMKM JEMAAT GBKP KELURAHAN KARANG JOANG \\ BALIKPAPAN
}

\author{
Rudy Pudjut Harianto \\ rudypudjut@gmail.com \\ STIE Madani Balikpapan
}

\begin{abstract}
This research aims to analyze the effect product and place toward satisfaction of budget training participants for small, micro and medium enterprises on Jemaat GBKP Balikpapan. This research used quantitative and qualitative method with primary data sources and using nonprobability sampling method with 32 respondents. Data analyse method that used in this research are validity and reliability test then classical assumption test (normality, multicollinierity, heteroscedasticity, autocorrelation) and Multiple Linier Regression Analyse (correlation coeficient, determination coeficient, $F$ test/varians analyse, $t$ test/significantion test). Accumulatively, coeficient correlation $(R)=0,537$ so that it can be said that the independent variables toward dependent variable in this research can giving the strong enough correlation. Result of Test Varians $(F)$ express the $H_{o}$ can be accepted because $F_{\text {count }}<F_{\text {table }}$ or $5,865<3,3277$. Its meaning that variable of product and place by together did have the influence which significant to satisfaction of budget training participants. The result of significantion test could be explained: (1) there are significant effect of product on satisfaction of budget training participants, and (2) there are not significant effect of place on satisfaction of budget training participants.
\end{abstract}

Keywords : product; place; satisfaction; budget training; small, micro and medium enterprises.

\section{PENDAHULUAN}

Usaha Mikro, Kecil dan Menengah (UMKM) merupakan kelompok usaha yang memiliki jumlah paling besar. Selain itu Kelompok ini terbukti tahan terhadap berbagai macam goncangan krisis ekonomi, sehingga sudah menjadi keharusan untuk memberikan penguatan kepada kelompok usaha mikro, kecil dan menengah dengan melibatkan banyak stakeholders. Kriteria usaha yang termasuk dalam Usaha Mikro, Kecil, dan Menengah telah diatur dalam payung hukum berdasarkan Undang-Undang Nomor 20 Tahun 2008 tentang Usaha Mikro, Kecil, dan Menengah (UMKM). Usaha Mikro, Kecil, dan Menengah (UMKM) 
memiliki peran yang cukup strategis dalam mengentaskan kemiskinan dan pengangguran yang ada di Indonesia.

Meskipun UMKM memiliki peran penting dan memberikan kontribusi yang cukup besar untuk Negara, bisnis UMKM masih perlu penguatan saat beroperasi sehingga perlu diberi dukungan agar bisnis UMKM ini bisa berjalan dengan lancar dan sukses. Dalam menjaga keberlangsungan UMKM, dibutuhkan perencanaan yang baik dalam mengelola sumber daya yang dimiliki terutama pengalokasian dan pencatatan melalui sistem penganggaran. Anggaran bagi UMKM bukan hanya berorientasi pada hasil, tetapi juga pada proses strategis yang dapat berfungsi sebagai alat perencanaan, alat koordinasi dan alat pengendalian. Salah satu jawaban yang dapat membantu para pelaku UMKM dalam penguatan pengelolaan finansial usahanya antara lain melalui kegiatan pelatihan pengelolaan keuangan usaha.

Berdasarkan uraian tersebut, penulis tertarik untuk melakukan analisis terhadap tingkat kepuasan pelaku UMKM dalam menerima materi pelatihan anggaran melalui penelitian yang berjudul "Pengaruh Produk dan Tempat terhadap Tingkat Kepuasan Peserta Pelatihan Penyusunan Anggaran bagi pelaku UMKM Jemaat GBKP Kelurahan Karang Joang Balikpapan".

Rumusan masalah merupakan suatu pertanyaan penelitian (research question) yang akan dicarikan jawabannya melalui pengumpulan data (Sugiyono, 2014:88). Berdasarkan latar belakang di atas, maka rumusan masalah dalam penelitian ini adalah: (1) Apakah produk dan tempat mempunyai pengaruh secara simultan terhadap tingkat kepuasan peserta pelatihan penyusunan anggaran bagi pelaku UMKM Jemaat GBKP Kelurahan Karang Joang Balikpapan ? (2) Apakah produk dan tempat mempunyai pengaruh secara parsial terhadap tingkat kepuasan peserta pelatihan penyusunan anggaran bagi pelaku UMKM Jemaat GBKP Kelurahan Karang Joang Balikpapan?

Tujuan yang diharapkan dari penelitian ini adalah untuk: (1) mengetahui pengaruh produk dan tempat secara simultan terhadap tingkat kepuasan peserta pelatihan penyusunan anggaran bagi pelaku UMKM Jemaat GBKP Kelurahan Karang Joang Balikpapan, (2) mengetahui pengaruh produk dan tempat secara parsial terhadap tingkat kepuasan peserta pelatihan penyusunan anggaran bagi pelaku UMKM Jemaat GBKP Kelurahan Karang Joang Balikpapan.

\section{KERANGKA TEORI}

\section{Definisi Produk}


Kotler dalam Kartajaya (2009:87-88) mendefinisikan produk merupakan segala sesuatu yang dapat ditawarkan, bisa berupa barang atau jasa yang dapat ditawarkan oleh suatu perusahaan. Pihak yang menggunakan produk atau membeli dan memanfaatkan nilai dari penawaran perusahaan untuk suatu atensi, akuisisi, kegunaan, atau konsumsi dan ditujukan untuk memuaskan pelanggan.

Alma (2014:139) mengatakan bahwa produk bukan hanya berbentuk sesuatu yang berwujud saja, seperti makanan, minuman, pakaian dan sebagainya. Akan tetapi juga sesuatu yang tidak berwujud seperti pelayanan jasa. Semua diperuntukan bagi pemuasan kebutuhan dan keinginan (needs and wants) dari konsumen.

Doyle (2013:326) mengemukakan produk mencakup kualitas produk, fitur, manfaat, gaya, desain, branding, pengemasan, servis, jaminan, garansi, siklus kehidupan, investasi, dan return (pengembalian nilai investasi). Adapun yang dimaksudkan sebagai produk dalam penelitian ini adalah bahan-bahan atau materi/modul yang disajikan dalam pelatihan penyusunan anggaran tersebut.

\section{Definisi Tempat}

Kotler dan Amstrong dalam Kartajaya (2009:91-93) mendefinisikan lokasi sebagai berikut place is the set of independent organization that help make a product or service available for use or consumption by the consumer or business user. Definisi tersebut mengartikan bahwa lokasi sebagai kumpulan dari organisasi-organisasi yang independen, yang membuat suatu barang atau jasa menjadi tersedia sehingga pelanggan dapat menggunakan atau mengkonsumsi barang atau jasa tersebut. Pelanggan yang dimaksud bisa merupakan pelanggan individu ataupun pelanggan bisnis. Ketersediaan dalam elemen tempat dapat diartikan menjadi beberapa hal, yaitu kenyamanan, keberadaan, variasi, hemat tempat dan waktu.

Menurut Tjiptono (2014:238) mendefinisikan bahwa lokasi menyangkut kemudahan akses terhadap jasa bagi para pelanggan komersial. Doyle (2013:326) mendeskripsikan place (lokasi atau tempat) mencakup saluran langsung atau tak langsung ke pasar, distribusi geografi, peliputan wilayah, gerai, ritel, lokasi pasar, katalog, inventory (persediaan barang dagang), logistik dan lokasi promosi penjualan.

\section{Definisi Kepuasan Konsumen}

Menurut Rambat Lupiyoadi (2006:192) bahwa kepuasan ialah merupakan tingkat perasaan seseorang menyatakan hasil perbandingan atas kinerja produk atau jasa yang diterima dan yang diharapkan. Fandy Tjiptono (2006:147) mengatakan bahwa kepuasan pelanggan 
adalah tingkat perasaan seseorang setelah membandingkan kinerja atau hasil yang ia rasakan dibandingkan dengan harapannya. Selain itu Fandy Tjiptono (2006:146) menyatakan bahwa kepuasan pelanggan merupakan evaluasi purnabeli dimana alternatif yang dipilih sekurangkurangnya memberikan hasil (outcome) sama atau melampaui harapan pelanggan, sedangkan ketidakpuasan timbul apabila hasil yang diperoleh tidak memenuhi harapan pelanggan.

Selanjutnya Sangadji dan Sopiah (2013:180) kepuasan konsumen diartikan sebagai suatu keadaan dimana harapan konsumen terhadap suatu produk atau jasa sesuai dengan kenyataan yang diterima oleh konsumen. Sedangkan menurut Mowen dan Minor dalam Sudaryono (2016:78) kepuasan konsumen didefinisikan sebagai keseluruhan sikap yang ditunjukkan konsumen atas barang dan jasa setelah mereka memperoleh dan menggunakannya.

Dari beberapa pengertian di atas dapat disimpulkan bahwa kepuasan konsumen adalah tingkat perasaan seseorang yang melakukan pembelian produk atau jasa untuk kebutuhan pribadinya setelah melakukan perbandingan antara kinerja produk atau jasa yang diberikan terhadap apa yang diharapkan oleh pemakai ataupun pelaku jasa tersebut. Harapan konsumen merupakan perkiraan atau keyakinan konsumen tentang apa yang akan diterimanya atau dirasakannya bila membeli atau mengkonsumsi suatu barang atau jasa. Sedangkan kinerja yang dirasakan adalah persepsi konsumen terhadap apa yang diterima atau dirasakan setelah mengkonsumsi suatu barang atau jasa yang dibeli. Suatu pelayanan dinilai memuaskan apabila pelayanan tersebut dapat memenuhi kebutuhan dan harapan pelanggan.

\section{Hubungan Kualitas Pelayanan dengan Kepuasan Pelanggan}

Tjiptono (2012:157) kualitas layanan ditentukan oleh kemampuan perusahaan memenuhi kebutuhan dan keinginan pelanggan sesuai dengan ekspektasi pelanggan. Kualitas layanan harus dimulai dari kebutuhan pelanggan dan berakhir dengan kepuasan pelanggan serta presepsi positif terhadap kualitas layanan. Dengan demikian jika kualitas pelayanan terus ditingkatkan sehingga mencapai apa yang diharapkan oleh konsumen atau pelanggan, maka akan puas. Kualitas pelayanan dan kepuasan pelanggan memiliki hubungan yang vital untuk menjalin suatu ikatan yang kuat dengan perusahaan.

Hasan (2008:59) menyatakan kemungkinan pelanggan akan menyatakan kepuasan dalam berbagai tingkatan sebagai berikut: (1) Kinerja > harapan $\rightarrow$ sangat puas yaitu apabila pelanggan mempresepsikan bahwa kinerja produk yang dinikmatinya lebih besar atau lebih tinggi dari yang diharapkan oleh pelanggan, maka pelanggan menyatakan bahwa mereka sangat puas, (2) Kinerja $=$ harapan $\rightarrow$ puas yaitu apabila pelanggan mempresepsikan bahwa kinerja produk yang dinikmatinya sama dengan yang diharapkan oleh pelanggan, maka pelanggan akan 
menyatakan bahwa mereka puas, (3) Kinerja $<$ harapan $\rightarrow$ kecewa yaitu apabila pelanggan mempresepsikan bahwa kinerja produk yang dinikmatinya lebih kecil atau lebih rendah dari yang diharapkan oleh pelanggan, maka pelanggan akan menyatakan bahwa mereka kecewa.

\section{Hipotesis}

Menurut Good dan Scates (1954) dalam buku statistika karya Suharyadi dan Purwanto (2009:81) menyatakan "bahwa hipotesis adalah sebuah dugaan atau referensi yang dirumuskan serta diterima untuk sementara yang dapat menerangkan fakta-fakta yang diamati dan digunakan sebagai petunjuk dalam pengambilan keputusan”. Jadi hipotesis merupakan jawaban sementara terhadap rumusan masalah penelitian.

Selanjutnya perumusan hipotesis dalam penelitian ini: (1) $\mathrm{H}_{1}$ : Diduga produk dan tempat mempunyai pengaruh secara simultan terhadap tingkat kepuasan peserta pelatihan penyusunan anggaran bagi pelaku UMKM Jemaat GBKP Kelurahan Karang Joang Balikpapan. (2) $\mathrm{H}_{2}$ : Diduga produk dan tempat mempunyai pengaruh secara parsial terhadap tingkat kepuasan peserta pelatihan penyusunan anggaran bagi pelaku UMKM Jemaat GBKP Kelurahan Karang Joang Balikpapan.

\section{METODE PENELITIAN}

\section{Jenis Penelitian}

Peneliti menggunakan jenis penelitian kombinasi yang oleh Sugiyono (2011:404) dinyatakan bahwa jenis penelitian kombinasi merupakan jenis penelitian yang dapat dilakukan dengan menggunakan suatu metode penelitian yang mengkombinasikan atau menggabungkan antara metode kuantitatif dengan metode kualitatif yang digunakan secara bersama-sama dalam suatu kegiatan penelitian, sehingga diperoleh data yang lebih komprehensif, valid, reliabel, dan objektif.

\section{Data Penelitian}

Jenis data yang digunakan dalam penelitian ini adalah data primer. Data primer merupakan data yang didapat dari sumber pertama baik dari individu atau perseorangan seperti hasil dari wawancara atau hasil pengisian kuesioner yang biasa dilakukan oleh peneliti (Umar, 2013:42). Data primer penelitian diperoleh dari hasil pengisian kuesioner (angket) dengan cara memilih salah satu jawaban dari masing-masing pernyataan melalui Skala Likert.

Menurut Sugiyono (2015:169) prosedur skala likert ini adalah menentukan skor atas pertanyaan dalam kuesioner yang disebarkan. Jawaban dari responden dibagi dalam lima 
kategori penilaian, masing-masing pertanyaan diberi skor 1-5. Alternatif jawaban dalam penelitian ini terdiri dari lima jawaban yang mengandung variasi nilai bertingkat yaitu: sangat tidak setuju (STS) diberi skor 1, tidak setuju (TS) diberi skor 2, kurang setuju (KS) diberi skor 3, setuju (S) diberi skor 4, dan sangat setuju (SS) diberi skor 5.

\section{Tehnik Pengumpulan Data}

Metode pengumpulan data yang digunakan adalah melalui angket atau kuisioner. Kuisioner adalah sejumlah pertanyaan secara tertulis yang akan dijawab oleh responden penelitian, agar peneliti memperoleh data lapangan / empiris untuk memecahkan masalah penelitian dan menguji hipotesis yang telah ditetapkan (Supardi, 2005:127).

\section{Populasi dan Sampel}

Sugiyono (2010:115) mendefinisikan populasi adalah wilayah generalisasi yang terdiri atas obyek/subyek yang mempunyai kualitas dan karakteristik tertentu yang ditetapkan oleh peneliti untuk dipelajari dan kemudian ditarik kesimpulannya.

Sedangkan pengertian sampel menurut Sugiyono (2012:73) adalah bagian dari jumlah dan karakteristik yang dimiliki oleh populasi tersebut, sampel yang diambil dari populasi tersebut harus betul-betul representatif (mewakili). Teknik pengambilan sampel dalam penelitian ini menggunakan teknik Nonprobability yaitu sampel jenuh atau sering disebut total sampling. Menurut Sugiyono (2014:124) sampel jenuh yaitu teknik penentuan sampel dengan cara mengambil seluruh anggota populasi sebagai responden atau sampel. Jadi jumlah sampel dalam penelitian ini adalah seluruh peserta pelatihan yang berjumlah 32 orang.

\section{Alat Analisis}

\section{Uji Validitas dan Reliabilitas}

Ghozali (2013: 52) mengungkapkan bahwa uji validitas digunakan untuk mengukur sah atau valid tidaknya suatu kuisioner. Suatu kuisioner dikatakan valid jika pertanyaan pada kuisioner mampu untuk mengungkapkan sesuatu yang akan diukur oleh kuisioner tersebut. Uji validitas berguna untuk mengetahui apakah ada pertanyaan-pertanyaan pada kuisioner yang harus dibuang/diganti karena dianggap tidak relevan (Umar, 2013:52). Untuk menghitung uji validitas, caranya ialah membandingkan nilai correlated item-total correlations ( $\mathrm{r}$ hitung) dengan hasil perhitungan $r$ tabel. Jika $r$ hitung lebih besar dari $r$ tabel pada tingkat signifikansi 0,05 dan nilai positif, maka pertanyaan atau indikator tersebut valid (Ghozali, 2013:52). Adapun ketentuan dalam uji ini, yaitu: 1) $r$ hitung $\geq \mathrm{r}$ tabel, artinya pertanyaan atau indikator tersebut 
dinyatakan valid; 2) $\mathrm{r}$ hitung $\leq \mathrm{r}$ tabel, artinya pertanyaan atau indikator tersebut dinyatakan tidak valid.

Uji reliabilitas digunakan untuk mengukur suatu kuisioner yang merupakan indikator dari variabel atau konstruk. Suatu kuisioner dikatakan reliabel atau handal jika jawaban seseorang terhadap pernyataan adalah konsisten atau stabil dari waktu ke waktu (Ghozali, 2013:47). Umar (2013:54) berpendapat bahwa uji reliabilitas berguna untuk menetapkan apakah instrumen yang dalam hal ini kuisioner dapat digunakan lebih dari satu kali, paling tidak oleh responden yang sama. Suatu konstruk atau variabel dikatakan reliabel jika memberikan nilai Cronbach Alpha $(\alpha)>0,60$, apabila nilai korelasi $<0,60$, maka dikatakan item tersebut kurang reliabel (Sujarweni, 2014:192).

\section{Uji Asumsi Klasik}

Uji asumsi klasik merupakan pra syarat analisis regresi berganda. Sebelum melakukan pengujian hipotesis, maka yang diajukan dalam penelitian adalah melakukan pengujian asumsi klasik meliputi: Uji Normalitas, Uji Multikolinearitas, Uji Heteroskedastisitas, dan Uji Autokorelasi yang masing-masing dapat dijelaskan sebagai berikut:

\section{Uji Normalitas :}

Umar (2010:77) mengemukakan bahwa uji normalitas berguna untuk mengetahui apakah variabel dependen, independen atau keduanya berdistribusi normal, mendekati normal atau tidak. Uji normalitas bertujuan untuk menguji apakah dalam model regresi, variabel pengganggu atau residual memiliki distribusi normal. Seperti diketahui bahwa uji t dan F mengasumsikan bahwa nilai residual mengikuti distribusi normal. Kalau asumsi ini dilanggar, maka uji statistik menjadi tidak valid dan jumlah sampel kecil. Ada dua cara untuk mendeteksi apakah residual berdistribusi normal atau tidak, yaitu dengan analisis grafik dan uji statistik (Ghozali, 2013:160):

a. Analisis grafik:

Pada prinsipnya, normalitas dapat dideteksi dengan melihat penyebaran data (titik) pada sumbu diagonal dari grafik atau dengan melihat histogram dari residualnya. Dasar pengambilan keputusan:

Jika data menyebar di sekitar garis diagonal dan mengikuti arah garis diagonal atau grafik histrogramnya menunjukkan pola distribusi normal, maka model regresi memenuhi asumsi normalitas. 
Jika data menyebar jauh dari diagonal dan/atau tidak mengikuti arah garis diagonal atau grafik histogram tidak menunjukkan pola distribusi normal, maka model regresi tidak memenuhi asumsi normalitas.

b. Analisis statistik:

Uji analisis secara statistik menggunakan program SPSS 22 for windows dengan output tabel One-Sample Kolmogorov-Smirnov Test diperoleh angka probabilitas atau Asymp.Sig (2-tailed). Nilai ini dibandingkan dengan 0,05 (dalam kasus ini menggunakan taraf signifikansi atau $\alpha=5 \%$ ) untuk pengambilan keputusan dengan pedoman jika nilai signifikansi atau nilai probabilitas $<0,05$, artinya adalah data residual terdistribusi tidak normal. Sedangkan jika nilai signifikansi atau nilai probabilitas $>0,05$, artinya adalah data residual terdistribusi normal.

\section{Uji Multikolinieritas :}

Ghozali (2013:105) mengemukakan bahwa uji multikolinieritas bertujuan untuk menguji apakah pada model regresi ditemukan adanya korelasi antar variabel bebas (independen). Uji multikolinieritas berguna untuk mengetahui apakah pada model regresi yang diajukan telah ditemukan korelasi kuat antar variabel multikolinearitas (Umar, 2010:80). Model regresi yang baik seharusnya tidak terjadi korelasi di antara variabel independen.

Untuk mendeteksi ada atau tidaknya multikolinieritas di dalam model regresi dapat dilakukan dengan cara melihat tolerance value atau nilai Variance Inflation Factor (VIF). Apabila nilai Variance Inflation Factor (VIF) tidak lebih dari 10, maka model terbebas dari multikolinieritas (Ghozali, 2013:106).

\section{Uji Heteroskedastisitas :}

Menurut Umar (2010:82) uji heteroskedastisitas dilakukan untuk mengetahui apakah dalam sebuah model regresi, terjadi ketidaksamaan varians dari residual suatu pengamatan ke pengamatan lain. Sedangkan Ghozali (2013:139) mengemukakan bahwa uji heteroskedastisitas bertujuan untuk menguji apakah dalam model regresi terjadi ketidaksamaan varian dari residual satu pengamatan ke pengamatan yang lain. Model regresi yang baik adalah yang homoskedastisitas atau tidak terjadi heteroskedastisitas.

Ada beberapa cara untuk mendeteksi ada atau tidaknya heteroskedastisitas, yaitu dengan melihat grafik plot antara nilai prediksi variabel terikat (dependen), yaitu ZPRED dengan residualnya SRESID. Deteksi ada tidaknya heteroskedastisitas dapat dilakukan dengan melihat ada tidaknya pola tertentu pada grafik scatterplot antara SRESID dan 
ZPRED dimana sumbu Y adalah Y yang telah diprediksi, dan sumbu X adalah residual (Y prediksi - Y sesungguhnya) yang telah di studentized.

Dasar analisis:

a. Jika ada pola tertentu, seperti titik-titik yang ada membentuk pola tertentu yang teratur (bergelombang, melebar kemudian menyempit), maka mengindikasikan telah terjadi heteroskedastisitas.

b. Jika tidak ada pola yang jelas, serta titik-titik menyebar di atas dan di bawah angka 0 pada sumbu Y, maka tidak terjadi heteroskedastisitas.

Untuk mengetahui apakah terjadi heteroskedastisitas atau tidak juga dapat dilakukan uji statistik dengan Uji Glejser. Dalam uji Glejser, diusulkan untuk meregres nilai absolut residual terhadap variabel bebas (Gujarati dalam Sujarweni, 2014:190). Pengujian ini dilakukan agar lebih menjamin keakuratan hasil. Pengambilan keputusan dalam uji ini adalah apabila nilai signifikan lebih besar dari 0,05 (>0,05), maka dapat disimpulkan model regresi tidak mengandung adanya heteroskedastisitas.

\section{Uji Autokorelasi :}

Uji autokorelasi berguna untuk mengetahui apakah dalam sebuah model regresi linier terdapat hubungan yang kuat baik positif maupun negatif antar data yang ada pada variabelvariabel penelitian (Umar, 2010:84). Data penelitian dapat berupa data time series atau cross section. Untuk data cross section, akan diuji apakah terdapat hubungan yang kuat antara data. Didukung oleh uji Durbin Watson (D-W) yang dapat digunakan untuk mendeteksi ada atau tidaknya autokorelasi. Model regresi yang baik adalah regresi yang terbebas dari autokorelasi (Umar, 2010:84).

Autokorelasi adalah korelasi antara anggota serangkaian observasi yang diurutkan menurut waktu atau ruang. Panduan mengenai angka D-W (Durbin-Watson) untuk mendeteksi autokorelasi dapat dilihat pada lampiran tabel D-W, dengan pengambilan keputusan sebagai berikut:

a. Jika nilai $D W$ berada di antara $d_{l}$ dan $4-d_{l}$ atau $d_{l}<D W<4-d_{l}$, maka signifikansi tidak terdapat autokorelasi.

b. Jika nilai $D W$ berada di antara $d_{u}$ dan $d_{l}\left(d_{u}<D W<d_{l}\right)$ atau $4-d_{l}<D W<4-d_{u}$, maka signifikansi tidak dapat disimpulkan atau ragu-ragu.

c. Jika nilai $D W$ berada di bawah $d_{u}\left(D W<d_{u}\right)$ atau $D W$ berada di atas $4-d_{u}\left(D W>4-d_{u}\right)$, maka signifikansi terdapat autokorelasi. 


\section{Analisis Regresi Linier Berganda :}

Priyatno (2014:148) menyatakan bahwa analisis regresi linier berganda digunakan untuk mengetahui pengaruh atau hubungan secara linier antara dua atau lebih variabel independen dengan satu variabel dependen. Perbedaan dengan regresi linier sederhana adalah bahwa regresi linier sederhana hanya menggunakan satu variabel independen dalam satu model regresi, sedangkan regresi linier berganda menggunakan dua atau lebih variabel independen dalam satu model regresi. Menurut Sugiyono (2011:275) model persamaan regresi linier berganda sebagai berikut:

$$
Y=b_{o}+b_{1} X_{1}+b_{2} X_{2}
$$

\section{Dimana:}

$\mathbf{Y}=$ Sebagai variabel terikat yaitu Tingkat Kepuasan Peserta Pelatihan.

$\mathbf{X}_{\mathbf{1}} \quad=$ Sebagai variabel bebas pertama yaitu Produk.

$\mathbf{X}_{\mathbf{2}}=$ Sebagai variabel bebas kedua yaitu Tempat.

bo $\quad$ Intercept $/$ Konstanta.

$\mathbf{b}_{1}, \mathbf{b}_{\mathbf{2}}=$ Koefisien Regresi.

Dari hasil persamaan di atas, dengan tingkat keyakinan yang dipergunakan adalah $95 \%$ dan taraf kesalahan 5\% selanjutnya akan dilakukan beberapa pengujian statistik lainnya sebagai berikut:

\section{Uji Koefisien Korelasi (R) :}

Uji koefisien korelasi digunakan untuk mengetahui hubungan antara dua atau lebih variabel independen terhadap variabel dependen secara serentak. Nilai R berkisar antara 0 sampai 1, nilai semakin mendekati 1 berarti hubungan yang terjadi semakin kuat, sebaliknya nilai semakin mendekati 0 , maka hubungan yang terjadi semakin lemah. Nilai R terletak antara -1 dan +1 atau $-1 \leq \mathrm{R} \leq+1$. Adapun pedoman untuk memberikan interpretasi koefisien korelasi menurut Sugiyono (2016:231) sebagai berikut:

$$
\begin{aligned}
& 0,00-0,199=\text { sangat rendah } \\
& 0,20-0,399=\text { rendah } \\
& 0.40-0,599=\text { sedang } \\
& 0,60-0,799=\text { kuat } \\
& 0,80-1,000=\text { sangat kuat }
\end{aligned}
$$




\section{Uji Koefisien Determinasi $\left(\mathbf{R}^{2}\right)$ :}

Uji koefisien determinasi digunakan untuk mengetahui persentase sumbangan pengaruh variabel independen secara serentak terhadap variabel dependen. Koefisien ini menunjukkan seberapa besar persentase variasi variabel independen yang digunakan dalam model mampu menjelaskan variabel variasi dependen. Jika $\left(\mathrm{R}^{2}\right)$ sama dengan 0 , maka tidak ada sedikitpun persentase sumbangan pengaruh yang diberikan variabel independen terhadap variabel dependen atau variasi variabel independen yang digunakan dalam model tidak menjelaskan sedikitpun variasi variabel dependen.

Sebaliknya apabila $\mathrm{R}^{2}$ sama dengan 1 , maka persentase sumbangan pengaruh yang diberikan variabel independen terhadap variabel dependen adalah sempurna atau variasi variabel independen yang digunakan model menjelaskan 100\% variasi variabel dependen.

\section{Uji Simultan/Analisis Varian (Uji F)}

Menurut Priyatno (2014:157) uji F digunakan untuk menganalisa pengaruh seluruh variabel independen secara bersama-sama (simultan) terhadap variabel dependen. Berdasarkan tabel ANOVA dapat dilakukan pengujian (Uji F) sebagai berikut:

a. Menentukan Hipotesis

Analisis Variance (Uji F/F test): Berdasarkan tabel ANOVA dapat dilakukan penentuan hipotesis sebagai berikut:

$\mathrm{H}_{0}$ : Secara simultan tidak terdapat pengaruh signifikan antara variabel produk dan tempat terhadap tingkat kepuasan peserta pelatihan.

$\mathrm{H}_{\mathrm{a}}$ : Secara simultan terdapat pengaruh signifikan antara variabel produk dan tempat terhadap tingkat kepuasan peserta pelatihan.

b. Menentukan tingkat signifikansi :

Tingkat signifikansi sebesar 5\% ( $\alpha=5 \%$ atau $\alpha=0,05)$

c. Menentukan $\mathrm{F}_{\text {tabel }}$ :

Dengan menggunakan tingkat keyakinan 95\% atau tingkat signifikansi 5\% (0,05), maka terlebih dahulu dicari nilai $t_{\text {tabel }}$ dengan menghitung nilai df1 yang diperoleh dengan cara k-1 (k adalah jumlah seluruh variabel dikurang 1) kemudian menghitung nilai df2 yang diperoleh dengan cara $\mathrm{n}-\mathrm{k}-1$ ( $\mathrm{n}$ adalah jumlah data dan $\mathrm{k}$ adalah jumlah varibel independen).

d. Kriteria Pengujiannya:

$\mathrm{H}_{\mathrm{o}}$ diterima apabila $\mathrm{F}_{\text {hitung }}<\mathrm{F}_{\text {tabel }}$ 
$\mathrm{H}_{\mathrm{o}}$ ditolak apabila $\mathrm{F}_{\text {hitung }}>\mathrm{F}_{\text {tabel }}$

\section{Uji Signifikansi/Uji t ( $t$ test )}

Priyatno (2014:159) menyatakan bahwa uji $\mathrm{t}$ adalah pengujian signifikansi untuk mengetahui pengaruh variabel-variabel independen $(\mathrm{X})$ terhadap variabel dependen $(\mathrm{Y})$ secara parsial apakah berpengaruh signifikan atau tidak. Untuk mengetahui hasil signifikan atau tidak angka $t_{\text {hitung }}$ akan dibandingkan dengan $t_{\text {tabel. }}$. Pengujian ini dapat dilakukan melalui langkah-langkah sebagai berikut:

a. Menentukan hipotesis:

$\mathrm{H}_{0}$ : Secara parsial tidak terdapat pengaruh signifikan antara variabel produk dan tempat terhadap tingkat kepuasan peserta pelatihan.

$\mathrm{H}_{\mathrm{a}}$ : Secara parsial terdapat pengaruh signifikan antara variabel produk dan tempat terhadap tingkat kepuasan peserta pelatihan.

b. Menentukan tingkat signifikansi atau taraf nyata:

Tingkat signifikansi menggunakan $=5 \%(0,05)$.

c. Menentukan $t_{\text {tabel }}$ :

Tabel distribusi t dicari pada $\alpha=5 \%: 2=2,5 \%$ (uji 2 sisi) dengan derajat kebebasan (df) adalah n-k-1. Dalam hal ini $\mathrm{n}$ adalah jumlah kasus dan $\mathrm{k}$ adalah jumlah variabel independen.

d. Kriteria pengujian:

$\mathrm{H}_{0}$ diterima apabila $-\mathrm{t}_{\text {tabel }} \leq \mathrm{t}_{\text {hitung }} \leq \mathrm{t}_{\text {tabel }}$

$\mathrm{H}_{0}$ ditolak apabila $\mathrm{t}_{\text {hitung }}>\mathrm{t}_{\text {tabel }}$ atau $\mathrm{t}_{\text {hitung }}<-\mathrm{t}_{\text {tabel }}$

\section{HASIL PENELITIAN DAN PEMBAHASAN}

\section{Uji Validitas dan Reliabilitas}

\section{Hasil Uji Validitas}

Uji validitas digunakan untuk mengukur valid tidaknya suatu kuisioner. Uji ini dilakukan dengan cara membandingkan hasil $r$ hitung dengan $r$ tabel. Dalam penelitian ini nilai $r$ tabel sebesar 0,3494 yang diperoleh dari nilai df $(n-2)$, yaitu $32-2=30$. Apabila nilai r hitung suatu item pernyataan besarnya lebih dari 0,3494 maka item tersebut dinyatakan valid. Berikut hasil perhitungan uji validitas untuk masing- masing variabel dengan menggunakan program SPSS 22 for Windows.

Tabel 1. 


\begin{tabular}{|c|c|c|c|c|c|}
\hline \multicolumn{6}{|c|}{ Hasil Uji Validitas Seluruh Variabel } \\
\hline No. & Variabel & Item & $\begin{array}{c}\mathbf{r} \\
\text { hitung }\end{array}$ & $\begin{array}{c}r \\
\text { tabel } \\
(5 \%) n= \\
32\end{array}$ & Keterangan \\
\hline \multirow{4}{*}{1.} & \multirow{4}{*}{ Produk $\left(\mathrm{X}_{1}\right)$} & item_1 & 0,786 & 0,3494 & Valid \\
\hline & & item_2 & 0,661 & 0,3494 & Valid \\
\hline & & item_3 & 0,517 & 0,3494 & Valid \\
\hline & & item_4 & 0,774 & 0,3494 & Valid \\
\hline \multirow[t]{4}{*}{2.} & \multirow[t]{4}{*}{ Tempat $\left(\mathrm{X}_{2}\right)$} & item_1 & 0,800 & 0,3494 & Valid \\
\hline & & item_2 & 0,775 & 0,3494 & Valid \\
\hline & & item_3 & 0,498 & 0,3494 & Valid \\
\hline & & item_4 & 0,774 & 0,3494 & Valid \\
\hline \multirow[t]{4}{*}{3.} & \multirow{4}{*}{$\begin{array}{c}\text { Tingkat } \\
\text { Kepuasan (Y) }\end{array}$} & item_1 & 0,818 & 0,3494 & Valid \\
\hline & & item_2 & 0,657 & 0,3494 & Valid \\
\hline & & item_3 & 0,742 & 0,3494 & Valid \\
\hline & & item_4 & 0,818 & 0,3494 & Valid \\
\hline
\end{tabular}

Sumber : Hasil Olah Uji SPSS 22.0

Dari tabel 1 tersebut, dapat diketahui bahwa nilai $r$ hitung dari setiap item pernyataan yang diuji nilainya lebih besar dari nilai $\mathrm{r}$ tabel. Oleh karena itu, seluruh item pernyataan pada variabel independen dan variabel dependen dinyatakan valid dan dapat digunakan sebagai alat pengumpul data.

\section{Hasil Uji Reliabilitas}

Uji reliabilitas digunakan untuk menunjukkan stabil atau tidaknya alat ukur yang digunakan atau sejauh mana konsistensi alat ukur tersebut. Hasil uji reliabilitas dinyatakan reliabel apabila hasil perhitungan memiliki koefisien keandalan sebesar $\alpha>0,60$. Berikut hasil pengujian reliabilitas:

Tabel 2.

Hasil Uji Reliabilitas Variabel $\mathrm{X}_{1}$ (Produk)

Reliability Statistics

\begin{tabular}{|r|c|}
\hline $\begin{array}{c}\text { Cronbach's } \\
\text { Alpha }\end{array}$ & $\begin{array}{c}\text { N of } \\
\text { Items }\end{array}$ \\
\hline, 601 & \\
\hline
\end{tabular}

Item-Total Statistics

\begin{tabular}{|l|r|r|r|r|}
\hline & $\begin{array}{c}\text { Scale Mean } \\
\text { if Item } \\
\text { Deleted }\end{array}$ & $\begin{array}{c}\text { Scale } \\
\text { Variance if } \\
\text { Item Deleted }\end{array}$ & $\begin{array}{c}\text { Corrected } \\
\text { Item-Total } \\
\text { Correlation }\end{array}$ & $\begin{array}{c}\text { Cronbach's } \\
\text { Alpha if Item } \\
\text { Deleted }\end{array}$ \\
\hline item_1 & 12.84 & 2.523 & .561 & .386 \\
item_2 & 12.78 & 3.273 & .471 & .503 \\
item_3 & 12.59 & 3.668 & .311 & .589 \\
item_4 & 13.25 & 2.065 & .348 & .650 \\
\hline
\end{tabular}


Berdasarkan tabel 2 di atas, nilai koefisien variabel $\mathrm{X}_{1}$ (Produk) menunjukkan angka sebesar 0,601. Hal ini mengindikasikan besarnya Cronbach's Alpha untuk variabel independen (Produk) lebih besar dari 0,60 (0,601 > 0,60), maka dapat dinyatakan bahwa variabel $\mathrm{X}_{1}$ bersifat konsisten dan stabil atau reliabel.

Tabel 3.

Hasil Uji Reliabilitas Variabel $\mathrm{X}_{2}$ (Tempat)

Reliability Statistics

\begin{tabular}{|r|r|}
\hline $\begin{array}{c}\text { Cronbach's } \\
\text { Alpha }\end{array}$ & $\begin{array}{c}\text { N of } \\
\text { Items }\end{array}$ \\
\hline, 645 & \\
\hline
\end{tabular}

Item-Total Statistics

\begin{tabular}{|l|r|r|r|r|}
\hline & $\begin{array}{c}\text { Scale Mean } \\
\text { if Item } \\
\text { Deleted }\end{array}$ & $\begin{array}{c}\text { Scale } \\
\text { Variance if } \\
\text { Item Deleted }\end{array}$ & $\begin{array}{c}\text { Corrected } \\
\text { Item-Total } \\
\text { Correlation }\end{array}$ & $\begin{array}{c}\text { Cronbach's } \\
\text { Alpha if Item } \\
\text { Deleted }\end{array}$ \\
\hline item_1 & 13.16 & 2.265 & .629 & .450 \\
item_2 & 13.34 & 2.426 & .611 & .480 \\
item_3 & 13.03 & 3.128 & .291 & .658 \\
item_4 & 13.72 & 1.757 & .361 & .731 \\
\hline
\end{tabular}

Berdasarkan tabel 3 di atas, nilai koefisien variabel $\mathrm{X}_{2}$ (Tempat) menunjukkan angka sebesar 0,645 Hal ini mengindikasikan besarnya Cronbach's Alpha untuk variabel independen (Tempat) lebih besar dari 0,60 (0,645>0,60), maka dapat dinyatakan bahwa variabel $\mathrm{X}_{2}$ bersifat konsisten dan stabil atau reliabel.

Tabel 4.

Hasil Uji Reliabilitas Variabel Y (Tingkat Kepuasan)

Reliability Statistics

\begin{tabular}{|r|r|}
\hline $\begin{array}{c}\text { Cronbach's } \\
\text { Alpha }\end{array}$ & $\begin{array}{c}\text { N of } \\
\text { Items }\end{array}$ \\
\hline, 749 & \\
\hline
\end{tabular}

Item-Total Statistics

\begin{tabular}{|l|r|r|r|r|}
\hline & $\begin{array}{c}\text { Scale Mean } \\
\text { if Item } \\
\text { Deleted }\end{array}$ & $\begin{array}{c}\text { Scale } \\
\text { Variance if } \\
\text { Item Deleted }\end{array}$ & $\begin{array}{c}\text { Corrected } \\
\text { Item-Total } \\
\text { Correlation }\end{array}$ & $\begin{array}{c}\text { Cronbach's } \\
\text { Alpha if Item } \\
\text { Deleted }\end{array}$ \\
\hline item_1 & 13.47 & 1.870 & .608 & .655 \\
item_2 & 13.50 & 2.581 & .463 & .735 \\
item_3 & 13.25 & 2.452 & .587 & .685 \\
item_4 & 13.50 & 1.806 & .587 & .675 \\
\hline
\end{tabular}


Berdasarkan tabel 4 di atas, nilai koefisien variabel Y (Tingkat Kepuasan) menun-jukkan angka sebesar 0,634. Hal ini mengindikasikan besarnya Cronbach's Alpha untuk variabel independen (Tingkat Kepuasan) lebih besar dari 0,60 (0,749 > 0,60), maka dapat dinyatakan bahwa variabel Y bersifat konsisten dan stabil atau reliabel.

\section{Uji Asumsi Klasik}

\section{Uji Normalitas}

Hasil uji normalitas menggunakan grafik P-P Plot masing-masing variabel dapat ditampilkan dan dijelaskan melalui grafik sebagai berikut:

\section{Gambar 1.}

Grafik Normalitas P-P Plot Variabel $\mathrm{X}_{1}$ (Produk)

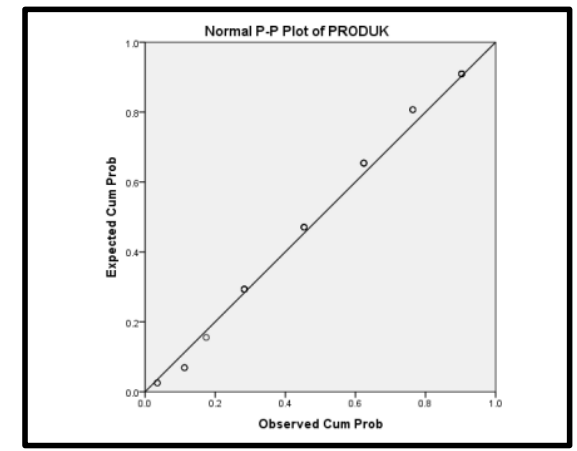

Gambar 2.

Grafik Normalitas P-P Plot Variabel X2 (Tempat)

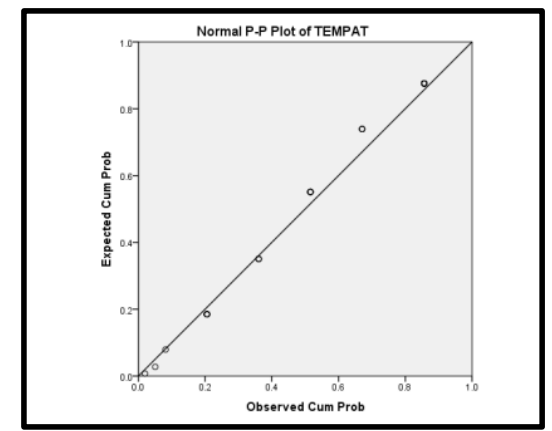

Gambar 3.

Grafik Normalitas P-P Plot Variabel Y (Tingkat Kepuasan)

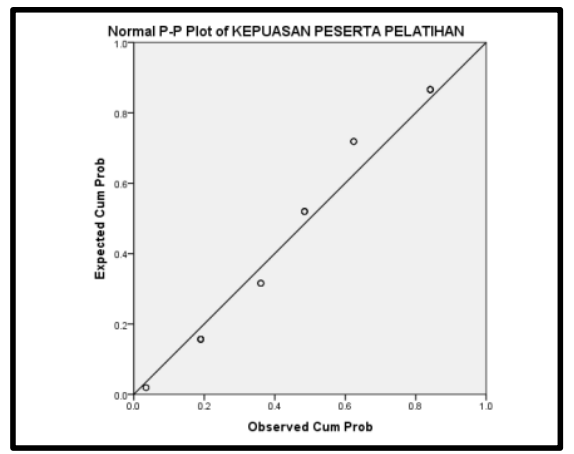


Berdasarkan tampilan grafik Normal P-Plot dari keenam variabel independen dan dependen tersebut, ternyata gambar distribusi dengan titik-titik data mengalami penyebaran di sekitar garis diagonal serta penyebaran titik-titik data searah mengikuti garis diagonal. Hal ini mengandung pengertian bahwa model regresi menunjukkan pola terdistribusi normal atau memenuhi asumsi normalitas.

Namun demikian uji normalitas residual menggunakan grafik belum cukup apabila tidak hati-hati karena secara visual kelihatan normal. Oleh sebab itu untuk melengkapi dan mempertajam uji grafiknya, maka perlu juga dilakukan uji statistik lain yaitu menggunakan uji statistik non parametrik Kolmogorov-Smirnov (K-S) sebagaimana dapat ditampilkan melalui tabel berikut ini:

Tabel 5.

One-Sample Kolmogorov-Smirnov Test

\begin{tabular}{|ll|r|r|r|}
\hline & & PRODUK & TEMPAT & $\begin{array}{c}\text { KEPUASAN } \\
\text { PESERTA } \\
\text { PELATIHAN }\end{array}$ \\
\hline$N$ & Mean & 32 & 32 & 32 \\
Normal Parameters ${ }^{a, b}$ & Std. & 2.127 & 17.75 & 17.91 \\
& Deviation & & & 1.890 \\
& Absolute & .123 & .157 & .179 \\
Most Extreme Differences & Positive & .091 & .128 & .156 \\
& Negative & -.123 & -.157 & -.179 \\
Kolmogorov-Smirnov $Z$ & & .696 & .887 & 1.010 \\
Asymp. Sig. (2-tailed) & & .719 & .411 & .259 \\
\hline
\end{tabular}

Nilai Asymp. Sig. (2-tailed) pada tabel One-Sample Kolmogorov-Smirnov Test $(K-S)$ di atas mendefinisikan bahwa seluruh variabel independen dan dependen yaitu: variabel $\mathrm{X}_{1}$ (Produk), variabel $\mathrm{X}_{2}$ (Tempat) dan variabel Y (Kepuasan Peserta Pelatihan) memenuhi asumsi normalitas atau data terdistribusi normal karena memiliki nilai di atas $0,05(>0,05)$.

\section{Uji Multikolinieritas}

Uji multikolinieritas bertujuan untuk menguji apakah model regresi ditemukan adanya korelasi antara variable bebas (independen). Untuk mendeteksi ada atau tidaknya multikolinieritas di dalam model regresi dapat dilakukan dengan cara melihat tolerance value atau nilai Variance Inflation Factor (VIF). Apabila nilai Variance Inflation Factor 
(VIF) tidak lebih dari 10, maka model terbebas dari multikolinieritas. Berikut hasil pengujian multikolinieritas:

Tabel 6.

Hasil Output SPSS Uji Multikolinieritas

\begin{tabular}{|ll|c|c|c|}
\hline \multirow{2}{*}{\multicolumn{2}{|c|}{ Model }} & \multicolumn{2}{|c|}{$\begin{array}{c}\text { Collinearity } \\
\text { Statistics }\end{array}$} \\
\cline { 2 - 3 } & Tolerance & VIF & \multirow{2}{*}{ Kesimpulan } \\
\hline $1 \quad$ (Constant) & & & \\
& PRODUK &, 998 & 1,002 & Tidak terjadi Multikolinieritas \\
\multicolumn{2}{|c|}{ TEMPAT } &, 998 & 1,002 & Tidak terjadi Multikolinieritas \\
\hline
\end{tabular}

a. Dependent Variable: KEPUASAN PESERTA PELATIHAN

Tabel di atas menunjukkan bahwa tidak terdapat variabel independen yang mempunyai nilai tolerance kurang dari 0,10 dan nilai VIF yang lebih besar dari 10. Oleh karena itu dapat disimpulkan bahwa tidak terjadi multikolinieritas antar variabel independen dalam model regresi.

\section{Uji Heteroskedastisitas}

Uji heteroskedastisitas bertujuan untuk menguji apakah dalam model regresi terjadi ketidaksamaan varians dari residual satu pengamatan ke pengamatan yang lain. Model regresi yang baik adalah yang tidak terjadi heteroskedastisitas atau dapat dikatakan terjadi homoskedastisitas.

Hasil uji heteroskedastisitas ditampilkan melalui grafik scatterplot sebagai berikut:

Gambar 4.

Grafik Scatterplot

Variabel Dependen Y

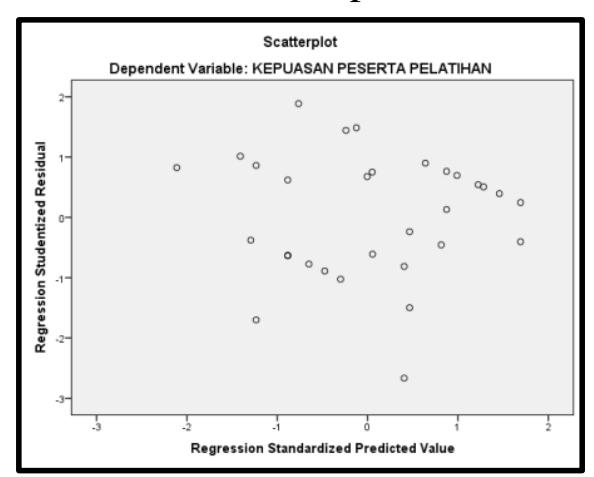

Berdasarkan gambar di atas dapat dilihat bahwa titik-titik yang ada tidak membentuk pola tertentu serta titik-titik menyebar di atas dan di bawah angka 0 pada sumbu $\mathrm{Y}$, sehingga dapat dijelaskan bahwa model regresi tersebut tidak terjadi heteroskedastisitas. Selain menggunakan scatterplot, uji heteroskedastisitas juga menggunakan pengujian statistik lainnya. Uji statistik yang dimaksud dalam penelitian ini adalah uji Glejser, dilakukan 
dengan cara meregresikan antara variabel independen dengan nilai absolute residual-nya. Apabila nilai signifikansi antara variabel independen dengan absolute $>0,05$ (lebih dari 0,05), maka tidak terjadi heteroskedastisitas. Berikut hasil uji Glejser-nya:

Tabel 7.

Hasil Output SPSS Uji Glejser

\begin{tabular}{|c|c|c|c|c|c|c|}
\hline & \multirow[t]{2}{*}{ Model } & \multicolumn{2}{|c|}{$\begin{array}{c}\text { Unstandardized } \\
\text { Coefficients }\end{array}$} & \multirow{2}{*}{$\begin{array}{c}\text { Standardized } \\
\text { Coefficients }\end{array}$} & \multirow[t]{2}{*}{$t$} & \multirow[t]{2}{*}{ Sig. } \\
\hline & & $B$ & Std. Error & & & \\
\hline \multirow{3}{*}{1} & $($ Constant $)$ & 3.630 & 1.818 & & 1.996 & .055 \\
\hline & PRODUK & -.101 & .072 & -.252 & -1.409 & .170 \\
\hline & TEMPAT & -.032 & .078 & -.074 & -.413 & .682 \\
\hline
\end{tabular}

a. Dependent Variable: RES2

Berdasarkan tabel 7 di atas, dapat dilihat nilai signifikan variabel Produk $\left(\mathrm{X}_{1}\right)=0,170$ dan variabel Tempat $\left(X_{2}\right)=0,682$ menunjukkan nilai lebih besar dari 0,05 $(>0,05)$, maka dapat dijelaskan bahwa tidak terjadi heteroskedastisitas.

\section{Uji Autokorelasi}

Prasyarat yang harus terpenuhi dalam uji ini adalah tidak adanya autokorelasi dalam model regresi. Metode pengujian yang dapat digunakan adalah dengan uji Durbin Watson. Hasil pengujian autokorelasi dengan menggunakan uji Durbin Watson (Uji DW) dapat dilihat pada tabel berikut:

Tabel 8.

Hasil Output SPSS Uji Autokorelasi

\begin{tabular}{|c|c|c|c|c|c|}
\hline Model & $\mathrm{R}$ & $\mathrm{R}$ Square & $\begin{array}{c}\text { Adjusted R } \\
\text { Square }\end{array}$ & $\begin{array}{c}\text { Std. Error of the } \\
\text { Estimate }\end{array}$ & Durbin-Watson \\
\hline 1 &, $537^{\mathrm{a}}$ &, 288 &, 239 & 1,649 & 2,010 \\
\hline
\end{tabular}

a. Predictors: (Constant), PRODUK, TEMPAT

b. Dependent Variable: KEPUASAN PESERTA PELATIHAN

Berdasarkan hasil perhitungan SPSS versi 22 dengan menggunakan metode penyesuaian parsial yang memuat kelambanan dari variabel dependennya, menghasilkan nilai dari Durbin Watson sebesar 2,010. Selanjutnya melalui tabel uji Durbin Watson $d_{l}$ dan $d_{u}$ pada level of significant $5 \%(0,05)$ diperoleh nilai sebagai berikut :

a. Nilai tabel $D W$ untuk $d_{u}(\mathrm{G}, \mathrm{k}, \mathrm{n})=(0,05 ; 2 ; 32)=1,3093$.

b. Nilai tabel $D W$ untuk $d_{l}(\mathrm{G}, \mathrm{k}, \mathrm{n})=(0,05 ; 2 ; 32)=1,5736$. 
Karena nilai uji Durbin Watson lebih besar dari nilai $d_{l}$ atau Durbin Watson berada di bawah4- $d_{l}(1,3093<2,010<2,6907)$ maka dapat ditarik hasil analisisnya bahwa dengan nilai $D W$ sebesar $\mathbf{2 , 0 1 0}$ menunjukkan tidak terjadi autokorelasi.

\section{Analisis Regresi Linier Berganda}

Uji ini digunakan untuk meramalkan nilai pengaruh dua variabel bebas atau lebih terhadap satu variabel terikat untuk membuktikan ada tidaknya hubungan fungsional atau hubungan kausal dua atau lebih variabel bebas yaitu Produk $\left(\mathrm{X}_{1}\right)$ dan Tempat $\left(\mathrm{X}_{2}\right)$ terhadap satu variabel terikat, yaitu Tingkat Kepuasan Peserta Pelatihan (Y). Berikut hasil perhitungan dengan menggunakan program SPSS 22.0 for windows.

Tabel 9.

Hasil Output SPSS Uji Regresi Linear Berganda

\begin{tabular}{|r|l|r|r|r|r|r|}
\hline \multirow{2}{*}{ Model } & \multicolumn{2}{|c|}{$\begin{array}{c}\text { Unstandardized } \\
\text { Coefficients }\end{array}$} & $\begin{array}{c}\text { Standardized } \\
\text { Coefficients }\end{array}$ & \multirow{2}{*}{$\mathrm{t}$} & \multirow{2}{*}{ Sig. } \\
\cline { 3 - 5 } \multicolumn{2}{|c|}{} & \multicolumn{1}{|c|}{ B } & Std. Error & \multicolumn{1}{c|}{ Beta } & & \\
\hline 1 & (Constant) & 6,560 & 3,542 & & 1,852 &, 074 \\
& PRODUK &, 415 &, 139 &, 467 & 2,980 &, 006 \\
& TEMPAT &, 238 &, 152 &, 246 & 1,566 &, 128 \\
\hline
\end{tabular}

a. Dependent Variable: KEPUASAN PESERTA PELATIHAN

Berdasarkan tabel 9 di atas, maka dapat dijelaskan ke dalam persamaan fungsi analisis regresi linear berganda, yaitu sebagai berikut:

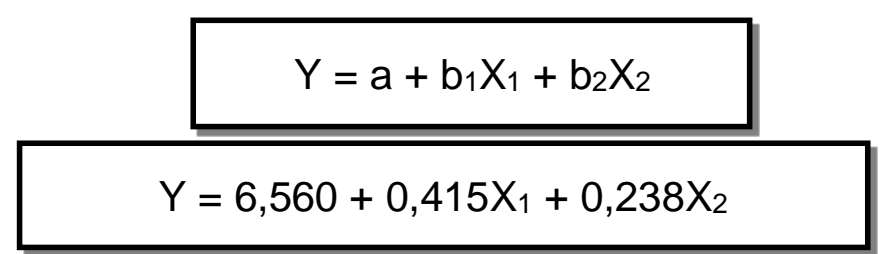

Selanjutnya interprestasi dari persamaan fungsi analisis regresi linear berganda di atas dapat diperoleh melalui penjelasan secara rinci berikut:

Nilai konstanta sebesar 6,560 artinya ketika variabel Produk $\left(\mathrm{X}_{1}\right)$ dan Tempat $\left(\mathrm{X}_{2}\right)$ dianggap konstan atau tidak ada perubahan, maka besarnya efektivitas Tingkat Kepuasan Peserta Pelatihan (Y) adalah sebesar 6,560.

Variabel Produk $\left(\mathrm{X}_{1}\right)$ mempunyai nilai koefisien sebesar 0,415 artinya bahwa setiap kenaikan 1 satuan variabel Produk $\left(\mathrm{X}_{1}\right)$, maka efektivitas Tingkat Kepuasan Peserta Pelatihan (Y) akan meningkat sebesar 0,415 satuan dengan asumsi bahwa variabel bebas yang lain tidak berubah atau konstan. 
Variabel Tempat $\left(\mathrm{X}_{2}\right)$ mempunyai nilai koefisien sebesar 0,238 artinya bahwa setiap kenaikan 1 satuan variabel Tempat $\left(\mathrm{X}_{2}\right)$, maka efektivitas Tingkat Kepuasan Peserta Pelatihan (Y) akan turun sebesar 0,238 satuan dengan asumsi bahwa variabel bebas yang lain tidak berubah atau konstan.

Dari hasil persamaan di atas, dengan tingkat keyakinan yang dipergunakan adalah $95 \%$ dan taraf kesalahan 5\% selanjutnya akan dilakukan beberapa pengujian statistik lainnya, sebagai berikut:

\section{Uji Koefisien Korelasi (R)}

Uji koefisien korelasi digunakan untuk mengetahui hubungan antara dua atau lebih variabel independen terhadap variabel dependen secara serentak. Hasil pengujian koefisien korelasi pada penelitian ini dapat dilihat pada tabel berikut:

Tabel 10.

Hasil Output SPSS Uji Koefisien Korelasi (R)

\begin{tabular}{|c|c|c|c|c|}
\hline Model & $\mathrm{R}$ & $\mathrm{R}$ Square & Adjusted R Square & Std. Error of the Estimate \\
\hline 1 &, $537^{\mathrm{a}}$ &, 288 &, 239 & 1,649 \\
\hline
\end{tabular}

a. Predictors: (Constant), PRODUK, TEMPAT

b. Dependent Variable: KEPUASAN PESERTA PELATIHAN

Tabel 10 menunjukkan bahwa nilai koefisien korelasi (R) sebesar 0,537. Apabila dilihat dari nilai interval koefisien korelasi tingkat 0,40 - 0,599 maka dapat disimpulkan bahwa terdapat hubungan tingkat korelasi yang sedang antara variabel Produk $\left(\mathrm{X}_{1}\right)$ dan Tempat $\left(\mathrm{X}_{2}\right)$ terhadap variabel Tingkat Kepuasan Peserta Pelatihan (Y).

\section{Uji Koefisien Determinasi $\left(\mathbf{R}^{2}\right)$}

Analisis determinasi $\left(\mathrm{R}^{2}\right)$ digunakan untuk menganalisis determinasi dalam regresi linier berganda. Pengujian ini digunakan untuk mengetahui persentase sumbangan pengaruh variabel independen secara serentak terhadap variabel dependen. Berikut hasil uji koefisien determinasi $\left(\mathrm{R}^{2}\right)$ :

Tabel 11.

Hasil Output SPSS Uji Koefisien Determinasi $\left(\mathrm{R}^{2}\right)$

\begin{tabular}{|l|l|l|l|l|}
\hline Model & $\mathrm{R}$ & R Square & Adjusted R Square & Std. Error of the Estimate \\
\hline
\end{tabular}




\begin{tabular}{|l|l|l|l|l|}
\hline 1 &, $537^{\mathrm{a}}$ &, 288 &, 239 & 1,649 \\
\hline
\end{tabular}

a. Predictors: (Constant), PRODUK, TEMPAT

b. Dependent Variable: KEPUASAN PESERTA PELATIHAN

Berdasarkan tabel 11 diperoleh nilai Adjusted R Square atau koefisien determinasi sebesar 0,239. Hal ini berarti bahwa variabel bebas dalam penelitian ini, yaitu Produk $\left(\mathrm{X}_{1}\right)$ dan Tempat $\left(\mathrm{X}_{2}\right)$ memiliki pengaruh sebesar 23,9\% terhadap variabel Tingkat Kepuasan Peserta Pelatihan (Y) dan sisanya 76,1\% dipengaruhi oleh faktor lain di luar model dalam penelitian ini.

\section{Uji Simultan/Analisis Varians (Uji F)}

Uji F pada dasarnya menunjukkan apakah semua variabel independen atau bebas yang dimasukkan dalam model mempunyai pengaruh secara bersama-sama (simultan) terhadap variabel dependen (terikat). Hasil dari uji $\mathrm{F}$ dapat dilihat pada tabel berikut:

Tabel 12.

ANOVA $^{\mathrm{a}}$

\begin{tabular}{|c|c|c|c|c|c|c|}
\hline & Model & $\begin{array}{l}\text { Sum of } \\
\text { Squares }\end{array}$ & df & Mean Square & $\mathrm{F}$ & Sig. \\
\hline \multirow{3}{*}{1} & Regression & 31,888 & 2 & 15,944 & \multirow[t]{3}{*}{$\overline{5,865}$} & \multirow[t]{3}{*}{, $007^{b}$} \\
\hline & Residual & 78,831 & 29 & \multirow[t]{2}{*}{2,718} & & \\
\hline & Total & 110,719 & 31 & & & \\
\hline
\end{tabular}

a. Dependent Variable : KEPUASAN PESERTA PELATIHAN

b. Predictors: (Constant), PRODUK,, TEMPAT

Berdasarkan hasil uji F pada tabel di atas, selanjutnya untuk mengetahui apakah variabelvariabel independennya memiliki pengaruh atau tidak, maka dilakukan langkah-langkah sebagai berikut:

a. Menguji hipotesis:

$H_{o}: \beta_{1}: \beta_{2}: \beta_{3} \neq 0$, artinya tidak ada pengaruh yang signifikan antara Produk dan Tempat terhadap Tingkat Kepuasan Peserta Pelatihan.

$\mathrm{H}_{\mathrm{a}}: \beta_{1}: \beta_{2}: \beta_{3}=0$, artinya ada pengaruh yang signifikan antara Produk dan Tempat terhadap Tingkat Kepuasan Peserta Pelatihan.

b. Menentukan $\mathrm{F}_{\text {tabel: }}$ 
Dengan menggunakan tingkat keyakinan $95 \%$ atau tingkat signifikansi 5\% (0,05), maka $\mathrm{df}_{1}$ dapat diperoleh dengan cara jumlah seluruh variabel dikurang $1(\mathrm{k}-1)$ dan $\mathrm{df}_{2}$ dengan cara n-k-1 (n adalah jumlah data dan k adalah jumlah varibel independen).

$$
\begin{aligned}
\mathrm{F}_{\text {tabel }} & =\alpha(\mathrm{k}-1 ; \mathrm{n}-\mathrm{k}-1) \\
& =0,05(3-1 ; 32-2-1) \\
& =0,05(2 ; 29) \\
& =\mathbf{3 , 3 2 7 7}
\end{aligned}
$$

c. Kriteria pengujian:

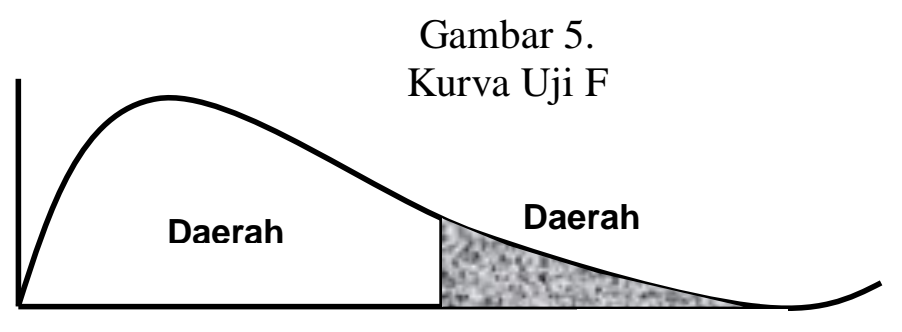

Dasar keputusannya:

$\mathrm{H}_{0}$ diterima apabila $\mathrm{F}_{\text {hitung }}<\mathrm{F}_{\text {tabel }}$

$\mathrm{H}_{0}$ ditolak apabila $\mathrm{F}_{\text {hitung }}>\mathrm{F}_{\text {tabel }}$

Berdasarkan perhitungan dan analisis data, diperoleh hasil $F_{\text {hitung }}$ sebesar 5,865 Dengan demikian $\mathrm{H}_{\mathrm{o}}$ diterima karena $\mathrm{F}_{\text {hitung }}>\mathrm{F}_{\text {tabel }}$ atau 5,865 > 3,3277 dan nilai signifikan sebesar $\mathbf{0 , 0 0 7}$ berada di atas taraf signifikansi 5\% (0,05). Hal ini menunjukkan bahwa variabel Produk dan Tempat secara simultan berpengaruh signifikan terhadap variabel Tingkat Kepuasan Peserta Pelatihan.

\section{Uji Signifikansi/Uji t ( $\mathbf{t}$ test )}

Uji t dilakukan untuk menunjukkan seberapa jauh pengaruh satu variabel independen secara individual dalam menerangkan variabel dependen. Pengujian ini akan melihat sejauh mana tingkat signifikansi masing-masing variabel independen terhadap variabel dependen. Berdasarkan tabel 10, maka uji t masing-masing variabel dilakukan dengan langkah-langkah sebagai berikut:

a. Menguji hipotesis:

$H_{o}: \beta_{1} \neq 0, \beta_{2} \neq 0, \beta_{3} \neq 0, \beta_{4} \neq 0$ dan $\beta_{5} \neq 0$ artinya tidak ada pengaruh yang signifikan masing-masing antara Produk dan Tempat terhadap Tingkat Kepuasan Peserta Pelatihan.

$\mathrm{H}_{\mathrm{a}}: \beta_{1}=0, \beta_{2}=0, \beta_{3}=0, \beta_{4}=0$ dan $\beta_{5}=0$ artinya ada pengaruh yang signifikan masingmasing antara Produk dan Tempat terhadap Tingkat Kepuasan Peserta Pelatihan.

b. Menentukan tabel: 
Dengan menggunakan tingkat keyakinan $95 \%$ atau tingkat signifikansi $5 \%(0,05)$ dan dengan derajat kebebasan (df) n-k-1 (n adalah jumlah data dan k adalah jumlah varibel independen), maka $t_{\text {tabel }}$ :

$$
\begin{aligned}
\mathrm{t}_{\text {tabel }} & =(\alpha / 2 ; \mathrm{n}-\mathrm{k}-1) \\
& =(0,05 / 2 ; 32-2-1) \\
& =(0,025 ; 29) \\
& =\mathbf{2 , 0 4 5 2}
\end{aligned}
$$

c. Kriteria pengujian:

Gambar 6.

Kurva Uji t Variabel Produk $\left(\mathrm{X}_{1}\right)$

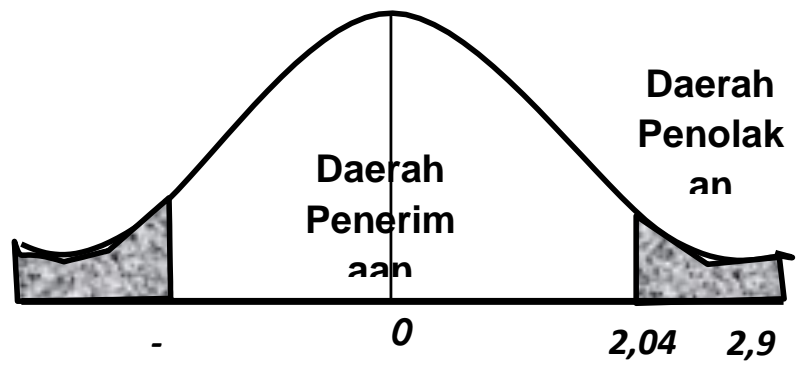

Dasar keputusannya:

$\mathrm{H}_{0}$ diterima apabila $\mathrm{t}_{\text {hitung }}<\mathrm{t}_{\text {tabel }}$

$\mathrm{H}_{0}$ ditolak apabila $\mathrm{t}_{\text {hitung }}>\mathrm{t}_{\text {tabel }}$

Berdasarkan hasil perhitungan dan analisis data sebagaimana tabel 9 diperoleh $t_{\text {hitung }}$ sebesar 2,980. Dengan demikian $H_{o}$ diterima karena $t_{\text {hitung }}>t_{\text {tabel }}$ atau 2,980 $>$ 2,0452 dan nilai signifikan sebesar $\mathbf{0 , 0 0 6}$ berada di bawah taraf signifikansi sebesar 5\% (0,05). Hal ini menunjukkan bahwa variabel Produk berpengaruh signifikan terhadap variabel Tingkat Kepuasan Peserta Pelatihan.

Gambar 7.

Kurva Uji t Variabel Tempat $\left(\mathrm{X}_{2}\right)$

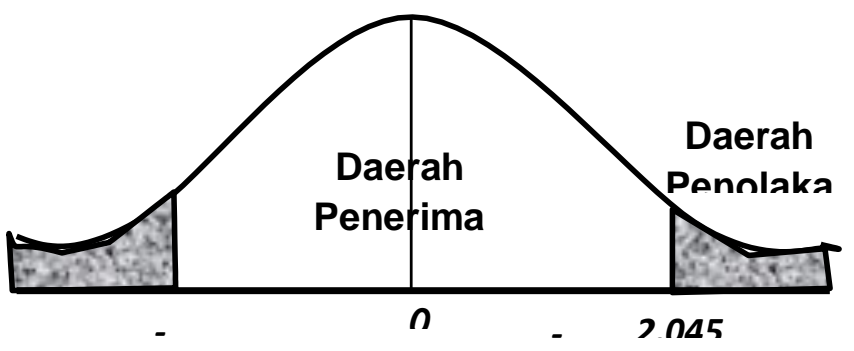


Dasar keputusannya:

$\mathrm{H}_{0}$ diterima apabila $\mathrm{t}_{\text {hitung }}<\mathrm{t}_{\text {tabel }}$

$\mathrm{H}_{0}$ ditolak apabila $\mathrm{t}_{\text {hitung }}>\mathrm{t}_{\text {tabel }}$

Berdasarkan hasil perhitungan dan analisis data sebagaimana tabel 9 diperoleh $t_{\text {hitung }}$ sebesar 1,566. Dengan demikian $\mathrm{H}_{\mathrm{o}}$ diterima karena $\mathrm{t}_{\text {hitung }}<\mathrm{t}_{\text {tabel }}$ atau $1,566<2,0452$ dan nilai signifikan sebesar $\mathbf{0 , 1 2 8}$ berada di atas taraf signifikansi sebesar 5\% (0,05). Hal ini menunjukkan bahwa variabel Tempat tidak berpengaruh signifikan terhadap variabel Tingkat Kepuasan Peserta Pelatihan.

\section{Pembahasan Hasil Penelitian}

\section{Pengaruh Produk terhadap Tingkat Kepuasan Peserta Pelatihan}

Dari hasil analisis data dalam penelitian ini melalui uji parsial (Uji t) menyatakan bahwa uji signifikansi variabel Produk terhadap Tingkat Kepuasan Peserta Pelatihan memiliki pengaruh. Hal ini disebabkan karena materi yang diberikan dengan waktu yang disediakan selama pemaparan relative cukup untuk menyelesaikan keseluruhan pokok bahasan dimulai dari materi kewirausahaan sampai dengan penyusunan anggaran sederhana bagi pelaku UMKM. Pokok bahasan dalam penyusunan anggaran dimulai dengan cara menyusun Neraca Awal periode akuntansi, kemudian dilanjutkan dengan penyusunan anggaran Laba Rugi sampai pada penyusunan anggaran Neraca Akhir periode akuntansi, dengan durasi waktu pelatihan selama kurang lebih satu jam dirasakan cukup memadai.

\section{Pengaruh Tempat terhadap Tingkat Kepuasan Peserta Pelatihan}

Dari hasil analisis data dalam penelitian ini melalui uji parsial (Uji t) menyatakan bahwa uji signifikansi variabel Tempat terhadap Tingkat Kepuasan Peserta Pelatihan tidak memiliki pengaruh. Berdasarkan realitas di lapangan bahwa komponen tempat / lokasi kurang mendukung kepuasan peserta pelatihan karena berada kurang lebih 1,2 km dari pinggir jalan utama yaitu J1. Soekarno Hatta Km. 10 Kelurahan Karang Joang Balikpapan yang tidak dilalui oleh jalur angkutan umum. Sedangkan yang berkaitan dengan kapasitas ruangan tempat pelatihan yang berada di dalam gereja dirasakan cukup memadai sehingga penyampaian materi dapat dilakukan maksimal. Hal lain yang dirasakan sebagai indikator pengaruh untuk variabel tempat adalah ketersediaan tempat parkir. Tempat parkir yang disediakan belum memadai karena parkir sebagian masih di badan jalan yang merupakan jalan baru untuk kendaraan roda dua dan roda empat. 


\section{PENUTUP}

\section{Kesimpulan}

1. Berkaitan dengan produk / materi pelatihan : bahwa materi yang diberikan dengan waktu yang disediakan relatif cukup untuk menyelesaikan keseluruhan pokok bahasan yaitu tentang kewirausahaan dan penyusunan anggaran sederhana bagi pelaku UMKM.

2. Berkaitan dengan tempat pelatihan : bahwa tempat/lokasi yang kurang mendukung kepuasan peserta pelatihan karena berada kurang lebih 1,2 km dari pinggir jalan utama yaitu Jl. Soekarno Hatta Km. 10 Kelurahan Karang Joang Balikpapan yang tidak dilalui oleh jalur angkutan umum.

\section{Saran}

1. Perlunya pihak penyelenggara pelatihan dapat mempersiapkan bahan/materi pelatihan dengan lebih terencana, termasuk lama waktu pelatihan (durasi) dapat disesuaikan dengan rencana materi yang akan disampaikan.

2. Perlunya penyelenggara pelatihan untuk mencarikan tempat yang terjangkau angkutan umum untuk lebih memudahkan peserta pelatihan mengikuti pelatihan tersebut, termasuk ketersediaan tempat parkir yang memadai. Sehingga jumlah peserta dapat dimungkinkan bertambah sesuai dengan harapan.

\section{DAFTAR PUSTAKA}

Alma, Buchari. 2014. Manajemen Pemasaran dan Pemasaran Jasa. Bandung : Alfabeta.

Charles Doyle. 2013. Dictionary of Marketing. United States : Oxford University Press Inc., New York

Ghozali, Imam. 2013. Aplikasi Analisis Multivariate Dengan Program IBM SPSS 21 Update PLS Regresi. Edisi Ketujuh. BP Universitas Diponegoro. Yogyakarta.

Hasan, Ali. 2008. Marketing. Medpress. Yogyakarta.

Kartajaya, Hermawan. 2009. The Official Mim Academy Coursebook Mark Plus Basics. Jakarta : Erlangga.

Lupiyoadi, Rambat dan A. Hamdani. 2006. Manajemen Pemasaran Jasa, Teori dan Praktek. Jakarta: Salemba Empat.

Priyatno, Duwi. 2014. SPSS 22 : Pengolahan Data Ter-praktis. Yogyakarta : ANDI Offset.

Sangadji, Etta Mamang dan Sopiah. 2013. Perilaku Konsumen: Pendekatan Praktis Disertai Himpunan Jurnal Penelitian. CV. Andi Offset. Yogyakarta. 
Sudaryono. 2016. Manajemen Pemasaran: Teori dan Inplementasinya. CV. Andi Offset. Yogyakarta.

Sugiyono. 2010. Metode Penelitian Bisnis. Cetakan Kelima Belas. Alfabeta. Bandung. . 2011. Metode Penelitian Kuantitatif, Kualitatif, dan $R \& D$. Bandung: CV. Alfabeta.

. 2012. Metode Penelitian Bisnis (Pendekatan Kuantitatif, Kualitatif, dan R\&D). Bandung: Alfabeta. . 2014. Metode Penelitian Manajemen. Cetakan ke 3. Bandung : Alfabeta. . 2015. Statistika Untuk Penelitian. Cetakan Ke Dua Puluh Enam. Alfabeta. Bandung. . 2016. Statistika untuk Penelitian. Bandung : ALFABETA.

Suharyadi dan Purwanto S.K. 2009. Statistika Untuk Ekonomi dan Keuangan Modern Edisi 2. Jakarta : Salemba Empat.

Sujarweni, Wiratna. 2014. SPSS untuk Penelitian. Yogyakarta : Pustaka Baru Press.

Supardi. 2005. Metodologi Penelitian Ekonomi dan Bisnis. Cetakan Pertama. UII Press. Yogyakarta.

Tjiptono, Fandy. 2005. Pemasaran Strategik. Yogyakarta : Andi Publisher. . 2006. Manajemen Jasa. Edisi Kedua. Cetakan Ketiga. Yogyakarta: Andi Offset. . 2012. Service Management: Mewujudkan Layanan Prima. CV. Andi Offset. Yogyakarta. , 2014. Pemasaran Jasa-Prinsip, Penerapan, dan Penelitian. Yogyakarta : Andi.

Umar, Husein. 2010. Desain Penelitian MSDM dan Perilaku Karyawan Paradigma Positivistik dan Berbasis Pemecahan Masalah. Jakarta : PT RajaGrafindo Persada.

. 2013. Metode Penelitian Untuk Skripsi dan Tesis. Edisi Kedua. Jakarta : PT Raja Grafindo Persada.

Undang-Undang Republik Indonesia Nomor 20 Tahun 2008 tentang Usaha Mikro, Kecil, dan Menengah (Lembaran Negara Republik Indonesia Tahun 2008 Nomor 93). 